\title{
GAMBARAN TINGKAT KESEGARAN JASMANI LANSIA LAKI-LAKI TIDAK ANEMIA DI DESA DAN KOTA
}

\author{
Yuniar Rosmalina'; Dewi Permaesih ${ }^{1}$ dan Dangsina Moeloek ${ }^{2}$ \\ ${ }^{1}$ Puslitbang Gizi dan Makanan Depkes RI, Bogor \\ ${ }^{2} \mathrm{FKUI}$, Jakarta
}

\section{ABSTRACT \\ PHISICAL FITNESS PROFILE OF NON ANEMIC MALE ELDERLY PEOPLE IN RURAL AND URBAN}

Background: Physical fitness is considered as one indicator of community health status of the community including elderly people. One of the benefit is elderly could live independently and do their daily activities without assistant. The study on Physical fitness of non anemic male elderly people has been conducted in the rural and the urban area.

Method: The data collection including 6 components of physical fitness (gait balance, muscle strength, endurance, body composition, flexibility and memory test), antropometric measurement (body weight, height and mid-arms circumference) and Hemoglobin level.

Result: The result shows that 217 elderly in rural and 281 elderly in urban area were participated on the study. The proportion of age was 42.9 percent in rural was $>70$ years and 37.2 percent in urban was 60-64 years old. Based on the physical fitness measurements the proportion of rural elderly who had low level physical fitness was 57.1 percent and 42.9 percent considered as moderate level. While in urban area the proportion of elderly who had low level physical fitness was 82.6 percent and 17.4 percent considered as moderate level. Out of 6 component of physical measurements body, cardiovascular endurance and body composition has high contribution to the different of physical fitness level between rural and urban.

Conclusion: The physical fitness level of non anemic male elderly in rural better compared to the urban.

Keywords: elderly, physical fitness, non anemic

\section{PENDAHULUAN}

$\mathrm{K}$ esegaran jasmani merupakan salah satu tolok ukur kesehatan masyarakat setiap kelompok masyarakat termasuk lansia. Lansia yang memiliki kesegaran jasmani yang tinggi selain sehat dan segar juga dapat melakukan aktivitas sehari-hari secara mandiri. Kesegaran jasmani yang buruk pada lansia sering membuat lansia terlihat tidak sehat dan sering mengalami cedera akibat terjatuh.

Di Indonesia proporsi lansia umur $>60$ tahun dari tahun ke tahun proporsinya meningkat dan pada tahun 2015 diramalkan jumlah lansia 24.5 juta orang ${ }^{(1)}$. Jumlah lansia yang besar dengan tingkat kesehatan yang buruk akan menjadi beban yang berat bagi pemerintah.

Proses penuaan tidak dapat dihindari oleh semua orang. Proses penuaan sering disertai oleh adanya peningkatan gangguan organ dan fungsi tubuh, terjadi perubahan komposisi tubuh, terjadi penurunan fat - free mass dan peningkattan fat mass. Pada proses penuaan ini massa otot persentasenya menurun. Dengan demikian terjadi penurunan "strength" atau kekuatan otot hingga 30-40 persen ${ }^{(2)}$. "Muscle strength" pada lansia juga berhubungan dengan masalah terjadinya keseimbangan yang mempunyai risiko lansia mudah terjatuh. 
Proses penuaan dapat diperlambat apabila mempunyai tingkat kesegaran jasmani yang baik. Lansia yang sehat dan bugar tidak akan menjadi beban orang lain, karena masih dapat mengatasi sendiri masalah hidup kesehariannya. Kesegaran jasmani pada lansia sangat penting untuk mendorong melakukan aktivitas sehari-hari dan kemandirian ${ }^{(3)}$.

Pada lansia yang sehat, namun tidak/kurang melakukan aktifitas fisik juga akan menyebabkan lansia terlihat tidak segar. Lansia yang tetap aktif melakukan aktifitas sehari-harinya akan mencegah terjadinya penurunan massa otot yang juga memacu nafsu makan yang berakibat pada peningkatan intake zat gizi.

Manfaat lain kesegaran jasmani pada lansia selain bisa mempertahankan produktifitas juga memperpanjang masa sehat atau menunda masa sakit. Penelitian bertujuan untuk mengetahui gambaran tingkat kesegaran jasmani lansia yang tidak anemia di desa dan kota.

\section{BAHAN DAN CARA}

\section{Rancangan penelitian}

Rancangan penelitian adalah Potong lintang dengan pendekatan komparatif exploratif.

\section{Lokasi penelitian}

Penelitian dilakukan di Kecamatan Ciampea yang mewakili desa yaitu Desa Situ Daun, Desa Cinangka dan Desa Benteng. Kecamatan Tebet Jakarta mewakili kota yaitu meliputi Kelurahan Manggarai Selatan, Bukit Duri dan Menteng Dalam. Pengumpulan data dilakukan mulai bulan April 2002 hingga Oktober 2002.

\section{Responden penelitian}

Responden adalah lansia laki-laki dengan umur 60 tahun ke atas, secara fisik dan klinis sehat, mempunyai kadar hemoglobin $\geq 13 \mathrm{~g} / \mathrm{dl}$ serta bersedia ikut dalam penelitian.

\section{Data yang dikumpulkan}

Identitas subjek dan karakteristik responden, yang meliputi status perkawinan, status pekerjaan, jenis pekerjaan, jumlah anggota keluarga, ada tidaknya anggota keluarga yang masih jadi tanggungan secara ekonomi dan tingkat pendidikan didapatken berdasarkan hasil wawancara

Pemeriksaan darah yaitu kadar hemoglobin darah dianalisis dengan metode Cyanmethemoglobin dengan batasan tidak anemia menurut $W H O \geq 13.0 \mathrm{~g} / \mathrm{dl}$ dan pengukuran Laju Endap Darah dilakukan untuk mengetahui responden tidak sedang menderita penyakit infeksi kronis.

Berat Badan diukur dengan mengunakan timbangan digital Seca dengan ketelitian $0.1 \mathrm{~kg}$. Tinggi badan diukur menggunakan alat microtoise dengan ketelitian $0.1 \mathrm{~cm}$. Lingkar Lengan Atas diukur menggunakan pita LLA Skinfold thickness dilakukan dengan mengukur ketebalan lapisan lemak pada empat posisi yaitu bicep, tricep, subcapula dan suprailiaca menggunakan alat Holtain caliper, dihitung jumlah rata-rata.

Tingkat kesegaran jasmani yang diukur meliputi 6 komponen yaitu kekuatan otot genggam tangan kiri dan kanan, kelenturan tubuh, keseimbangan tubuh, ketahanan jantung paru, komposisi tubuh dan kemampuan memori.

Kekuatan otot tangan genggam tangan diukur menggunakan alat hand grip dynamometer, pengukuran dilakukan 3 kali dan diambil nilai yang tertinggi.

Kelenturan tubuh diukur dengan metode "Sit and Reach" dan kemampuan mengangkat kaki pada posisi responden berbaring.

Keseimbangan tubuh meliputi keseimbangan dinamis dan statis. Keseimbangan dinamis dilakukan dengan cara meminta responden berjalan mengikuti garis lurus sepanjang 3- 5 meter. Kategori baik bila bisa berjalan tidak keluar garis. Keseimbangan statis dilihat keseimbangan tubuh pada saat mata terbuka dan tertutup pada posisi berdiri tegak.

Ketahanan jantung paru diukur nenggunakan sepeda statis Monark, sesuai 
kemampuan responden dengan beban minimal dan dengan pengawasan dokter.

Komposisi tubuh meliputi Indeks Massa Tubuh, dan persentase lemak tubuh yang dihitung berdasarkan hasil pengukuran ketebalan lemak
Kemampuan kognitif dan memori dilakukan dengan cara meminta responden untuk menyebutkan kembali 10 benda yang biasa digunakan dan telah ditunjukkan sebelumnya (sendok, piring, gelas, korek api, mangkok cuci tangan, serbet, jam tangan, sisir, kaca mata dan bolpoint) .

Tabel 1

Kategori dan nilai skor komponen kesegaran jasmani

\begin{tabular}{|c|c|c|c|}
\hline \multicolumn{3}{|c|}{ Komponen Kesegaran Jasmani } & \multirow{2}{*}{$\begin{array}{c}\text { Skor } \\
1 \\
2 \\
3\end{array}$} \\
\hline 1. Keseimbangan Tubuh & a. Statis & $\begin{array}{l}\text { - Mata tertutup dan terbuka badan } \\
\text { goyang } \\
\text { - Mata tertutup badan goyang } \\
\text { - Mata tertutup dan terbuka badan } \\
\text { tidak goyang }\end{array}$ & \\
\hline & b. Dinamis & $\begin{array}{l}\text { - Keluar garis } \\
\text { - Tidak keluar garis }\end{array}$ & $\begin{array}{l}1 \\
2\end{array}$ \\
\hline \multirow[t]{2}{*}{ 2. Kelenturan tubuh } & a. Mengangkat kaki & $\begin{array}{l}-<45 \text { derajat } \\
-45-80 \text { derajat } \\
->80 \text { derajat }\end{array}$ & $\begin{array}{l}1 \\
2 \\
3\end{array}$ \\
\hline & b. Sit \& Reach & $\begin{array}{l}<-6.5 \mathrm{~cm} \\
6.5-(-1.5) \mathrm{cm} \\
-1.5-11.5 \mathrm{~cm} \\
11.5-19 \mathrm{~cm} \\
>19 \mathrm{~cm} \\
\end{array}$ & $\begin{array}{l}1 \\
2 \\
3 \\
4 \\
5 \\
\end{array}$ \\
\hline \multirow[t]{2}{*}{ 3. Kekuatan otot genggam tangan } & a. Tangan kanan & $\begin{array}{l}<41 \mathrm{~kg} \\
41-47 \mathrm{~kg} \\
48-61 \mathrm{~kg} \\
62-69 \mathrm{~kg}\end{array}$ & $\begin{array}{l}1 \\
2 \\
3 \\
4\end{array}$ \\
\hline & b. Tangan kiri & $\begin{array}{l}<39 \mathrm{~kg} \\
39-42 \mathrm{~kg} \\
43-55 \mathrm{~kg} \\
56-57 \mathrm{~kg}\end{array}$ & $\begin{array}{l}1 \\
2 \\
3 \\
4\end{array}$ \\
\hline 4. Ketahanan kardiovaskuler & Sepeda statis & $\begin{array}{l}\text { - Kurang sekali VO2max< } 21 \\
\text { - Kurang VO2max } 22-26 \\
\text { - Cukup VO2max } 27-35 \\
\text { - Baik VO2max } 36-39 \\
\text { - Baik sekali VO2max }>40 \\
\end{array}$ & $\begin{array}{l}1 \\
2 \\
3 \\
4 \\
5\end{array}$ \\
\hline 5. Komposisi tubuh & persen Lemak tubuh & $\begin{array}{l}\text { - Kurang < } 5 \text { persen } />20 \text { persen } \\
\text { - Lebih } 18-19 \text { persen } \\
\text { - Cukup } 15-17 \text { persen } \\
\text { - Baik } 11 \text { - 14persen } \\
\text { - Baik sekali } 5-10 \text { persen }\end{array}$ & $\begin{array}{l}1 \\
2 \\
3 \\
4 \\
5\end{array}$ \\
\hline 6. Kemampuan memori & $\begin{array}{l}\text { Jumlah nama barang } \\
\text { yang diingat }\end{array}$ & $\begin{array}{l}<7 \\
7-10\end{array}$ & $\begin{array}{l}1 \\
2\end{array}$ \\
\hline
\end{tabular}

Reference: $3,4,5$

\section{Analisis data}

Data dianalisis untuk mengetahui sebaran, rata-rata. Tingkat kesegaran jasmani dihitung dengan memberikan skor pada tiap-tiap tes kesegaran jasmani, makin 
tinggi skor makin tinggi kemampuan kesegaran jasmaninya.

Tingkat kesegaran jasmani dihitung dengan menjumlahkan skor ke 6 komponen kesegaran jasmani yang diukur yaitu kelenturan tubuh, keseimbangan tubuh, kekuatan otot genggam tangan, ketahanan jantung paru, komposisi tubuh dan kemampuan memori. Tabel 1 menunjukkan kategori dan nilai skor yang diberikan dari setiap pengukuran komponen kesegaran jasmani.
Tingkat kesegaran jasmani adalah ratarata skor dari hasil pengukuran 6 komponen kesegaran jasmani yang meliputi keseimbangan tubuh, kelenturan tubuh, kekuatan otot genggam tangan, ketahanan kardiovaskuler, komposisi tubuh dan kemampuan memori.

Skor $<=2 \quad$ adalah kurang Skor 2.1 - 3.9 adalah cukup Skor $>3.9$ adalah baik

Tabel 2

Sebaran Sosiodemografi Responden menurut Desa dan Kota

\begin{tabular}{|c|c|c|c|c|c|c|c|}
\hline \multirow{2}{*}{\multicolumn{2}{|c|}{ Sosiodemografi }} & \multicolumn{2}{|c|}{ Desa $(n=217)$} & \multicolumn{2}{|c|}{ Kota $(n=281)$} & \multicolumn{2}{|c|}{ Total } \\
\hline & & $\mathrm{n}$ & $\%$ & $n$ & $\%$ & $\mathrm{n}$ & $\%$ \\
\hline \multicolumn{8}{|c|}{ Umur responden * } \\
\hline & $60-64$ tahun & 80 & 36,9 & 104 & 37,0 & 184 & 36,9 \\
\hline 2. & $65-69$ tahun & 44 & 20,3 & 81 & 28,8 & 125 & 25,1 \\
\hline 3 & $\geq 70$ tahun & 93 & 42,9 & 96 & 34,2 & 189 & 38,0 \\
\hline \multicolumn{8}{|c|}{ Status Perkawinan } \\
\hline 1 & Menikah & 193 & 88,9 & 246 & 87,2 & 439 & 88,0 \\
\hline 2. & Duda & 24 & 11,1 & 36 & 12,8 & 60 & 12,0 \\
\hline \multicolumn{8}{|c|}{ Status Pekerjaan * } \\
\hline 1 & Bekerja & 155 & 71,4 & 92 & 32,7 & 247 & 49,6 \\
\hline 2. & Tidak bekerja & 62 & 28,6 & 189 & 67,3 & 251 & 50,4 \\
\hline \multicolumn{8}{|c|}{ Jenis Pekerjaan Sekarang * } \\
\hline 1 & Pensiunan & 28 & 12,9 & 130 & 46,3 & 158 & 31,7 \\
\hline 2. & Pedagang warung & 18 & 8,3 & 26 & 9,3 & 44 & 8,8 \\
\hline 3 & Pedagang Keliling & 9 & 4,1 & 3 & 1,1 & 12 & 2,4 \\
\hline 4 & Buruh bangunan & 47 & 21,7 & 5 & 1,8 & 52 & 10,4 \\
\hline 5 & Buruh Pabrik & 7 & 3,2 & 3 & 1,1 & 10 & 2,0 \\
\hline 6 & Petani & 44 & 20,3 & 0 & 0 & 44 & 8,8 \\
\hline 7 & Tidak kerjs & 34 & 15,7 & 59 & 21,0 & 93 & 18,7 \\
\hline 8 & Lain-lain & 30 & 13,8 & 55 & 19,6 & 85 & 17,1 \\
\hline \multicolumn{8}{|c|}{ Jenis Pekerjaan produktif * } \\
\hline 1 & PNS/Kantor & 35 & 16,1 & 138 & 49,1 & 173 & 34,7 \\
\hline 2. & Warung & 32 & 14,7 & 22 & 7,8 & 54 & 10,8 \\
\hline 3 & Pedagang Keliling & 40 & 18,4 & 29 & 10,3 & 69 & 13,9 \\
\hline 4 & Buruh bangunan & 54 & 24,9 & 74 & 26,3 & 128 & 25,7 \\
\hline 5 & Buruh Pabrik & 16 & 7,4 & 9 & 3,2 & 25 & 5,0 \\
\hline 6 & Petani & 22 & 10,1 & 2 & 0,7 & 24 & 4,8 \\
\hline 7. & Lain- lain & 18 & 8,3 & 7 & 2,5 & 25 & 5,0 \\
\hline \multicolumn{8}{|c|}{ Jumlah ART * } \\
\hline 1 & $\leq 5$ & 147 & 67,7 & 158 & 56,2 & 305 & 61,2 \\
\hline 2. & $>5$ & 70 & 32,7 & 123 & 43,8 & 193 & 38,8 \\
\hline \multicolumn{8}{|c|}{ Beban Tangqungan } \\
\hline 1 & Ada & 112 & 51,6 & 125 & 44,5 & 237 & 47,6 \\
\hline 2. & Tidak & 105 & 48,4 & 156 & 55,5 & 262 & 52,4 \\
\hline
\end{tabular}


HASIL

\section{Karakteristik Responden}

Proporsi umur responden di desa tertinggi pada kelompok umur $>70$ tahun (42,9persen), sedangkan di kota proporsi umur responden terdapat pada kelompok umur yang lebih muda yaitu kelompok umur 60 - 64 tahun (37,2persen). Status perkawinan responden baik di desa maupun kota lebih dari 80 persen adalah menikah. Terdapat perbedaan proporsi status pekerjaan lansia sekarang, 71,4 persen responden di desa masih bekerja, sementara di kota 32,7 persen yang masih bekerja, walaupun rata-rata waktu yang digunakan untuk bekerja tidak penuh hanya berkisar 3 jam sehari.

Tabel 2 menunjukkan jenis pekerjaan lansia yang sekarang dilakukan di desa proporsi teringgi adalah sebagai buruh bangunan dan petani $(21,7 \%$ dan $20,3 \%)$, sedangkan di kota proporsi tertinggi adalah pensiunan $(46,3 \%)$. Jenis pekerjaan pada usia produktif di desa proposinya adalah sebagai buruh bangunan 24,9 persen dan di kota sebagian besar $(49,1 \%)$ sebagai pegawai negeri atau pegawai kantor. Proporsi jumlah anggota rumah tangga di desa yang mempunyai jumlah anggota keluarga sebanyak 1 - 5 orang sebanyak 67,7 persen dibandingkan di kota hanya 56,2 persen. Beban keluarga dalam arti ada anggota keluarga yang masih sekolah atau keluarga yang dibiayai di desa adalah 51,6 persen masih dalam tanggungan sedangkan di kota lebih rendah yaitu 44,3 persen.

Tabel 3 menunjukkan sebaran responden menurut lamanya pendidikan yang diperoleh baik di desa maupun di kota. Sebanyak 77 persen responden di desa mengenyam pendidikan selama kurang dari 6 tahun, sementara di kota hanya 30,2 persen responden yang mengenyam pendidikan kurang dari 6 tahun. Proporsi lamanya waktu yang digunakan untuk pendidikan di kota terlihat menyebar pada setiap kelompok tahun.

Tabel 3

Sebaran Lama Waktu Pendidikan Responden menurut Desa dan Kota

\begin{tabular}{|c|c|c|c|c|c|c|}
\hline \multirow[b]{2}{*}{ Lama pendidikan } & \multicolumn{2}{|c|}{ Desa } & \multicolumn{2}{|c|}{ Kota } & \multicolumn{2}{|c|}{ Total } \\
\hline & $\mathrm{n}$ & $\%$ & $\mathrm{n}$ & $\%$ & $\mathrm{n}$ & $\%$ \\
\hline 1. $<6$ tahun & 167 & 77,0 & 85 & 30,2 & 252 & 50,6 \\
\hline 2. 6-8 Tahun & 28 & 12,9 & 61 & 21,7 & 89 & 17,9 \\
\hline 3. $9-11$ Tahun & 15 & 6,9 & 65 & 23,1 & 80 & 16,1 \\
\hline 4. $>11$ tahun & 7 & 3,2 & 70 & 24,9 & 77 & 15,5 \\
\hline
\end{tabular}

I bermakna $p<0,05$

Hasil Pengukuran Anthropometri dan
Komposisi Tubuh Responden
Pengukuran antropometri yang
dilakukan meliputi penimbangan berat

Tabel 4

Hasil Pengukuran Antropometri Responden menurut Desa dan Kota

\begin{tabular}{|c|c|c|c|c|}
\hline Hasil Pengukuran & \multicolumn{2}{|c|}{ Desa (217) } & \multicolumn{2}{c|}{ Kota (281) } \\
\cline { 2 - 5 } Antropometri & Rata-rata & SD & Rata-rata & SD \\
\hline${\text { Berat Badan }(\mathrm{Kg})^{*}}_{\text {Tinggi Badan (Cm) }}^{47,8}$ & 7,6 & 57,5 & 11,3 \\
LILA (Cm) & 156,8 & 6,3 & 160,2 & 5,7 \\
& 24,7 & 2,9 & 26,0 & 3,5
\end{tabular}




\begin{tabular}{|c|c|c|c|c|}
\hline Indeks Massa Tubuh * & 19,4 & 2,7 & 22,3 & 3,8 \\
\hline
\end{tabular}

Hasil pengukuran antropometri dan perhitungan komposisi tubuh terlihat ratarata lebih tinggi di kota dibandingkan desa. Status gizi yang ditunjukkan dengan kategori IMT memperlihatkan lansia di desa yang kurus proporsinya lebih tinggi $(39,6 \%)$ dibandingkan di kota $(16,7 \%)$, sebaliknya lansia di kota proporsi yang gemuk lebih tinggi $(24,6 \%)$ dibandingkan dengan di desa $(3,2 \%)$.

\section{Pengukuran Kesegaran Jasmani Lansia}

\section{Keseimbangan Dinamis dan Statis}

Keseimbangan dinamis diukur dengan cara meminta responden untuk berjalan dengan kaki satu garis mengikuti garis lurus sepanjang 3 meter. Pada Gambar 1 terlihat baik lansia di desa maupun kota keseimbangannya masih baik yang ditunjukkan lebih dari 90 persen responden masih bisa berjalan secara lurus mengikuti arah garis, dengan tidak melihat pada garis, penglihatan lurus ke depan.

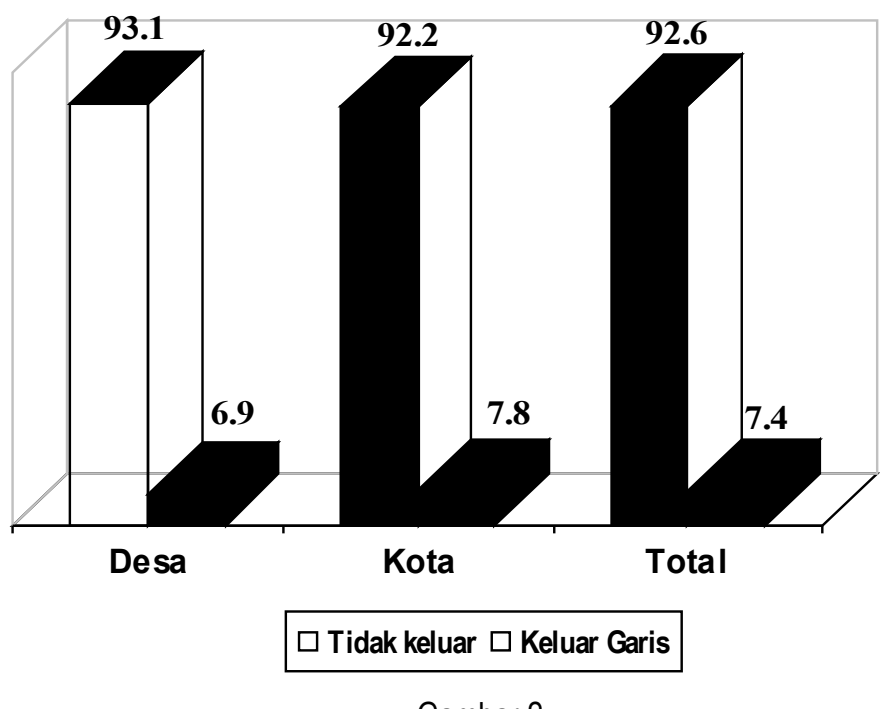

Gambar 2

Proporsi Keseimbangan Tubuh Dinamis menurut Desa dan Kota

Keseimbangan statis diukur dengan cara meminta responden untuk berdiri tegak, kemudian memejamkan mata. Dilakukan pengamatan keseimbangan tubuh dengan melihat perubahan gerakan tubuh. Hasil pengukuran keseimbangan statis menunjukkan proporsi tertinggi baik di desa maupun kota ditemukan pada keseimbangan baik, yakni ketika memejamkan mata tubuh tidak bergoyang. 


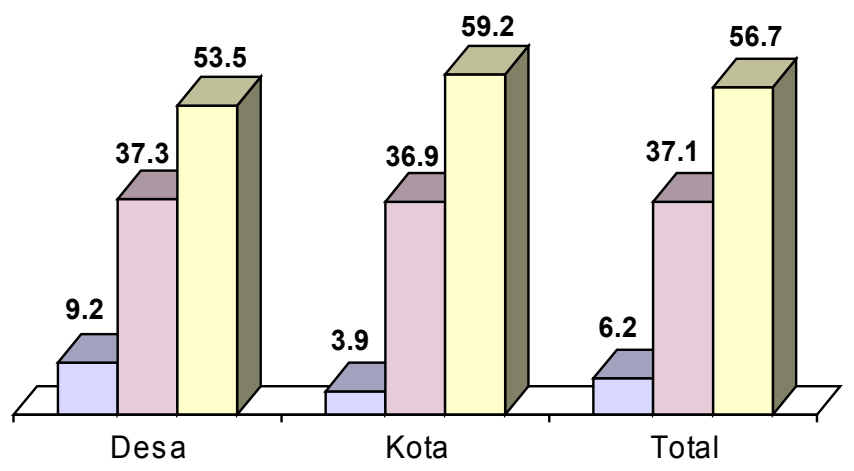

$\square$ Katagori $1 \quad \square$ Katagori $2 \quad \square$ Katagori 3

Gambar 3

Proporsi Keseimbangan Tubuh Statis menurut Desa dan Kota

\section{Kelenturan Tubuh}

Komponen kelenturan tubuh yang diukur adalah kelenturan kaki kiri dan kanan dengan mengangkat kaki pada posisi badan berbaring dan jarak jangkauan pada posis duduk dengan cara "Sit and Reach".

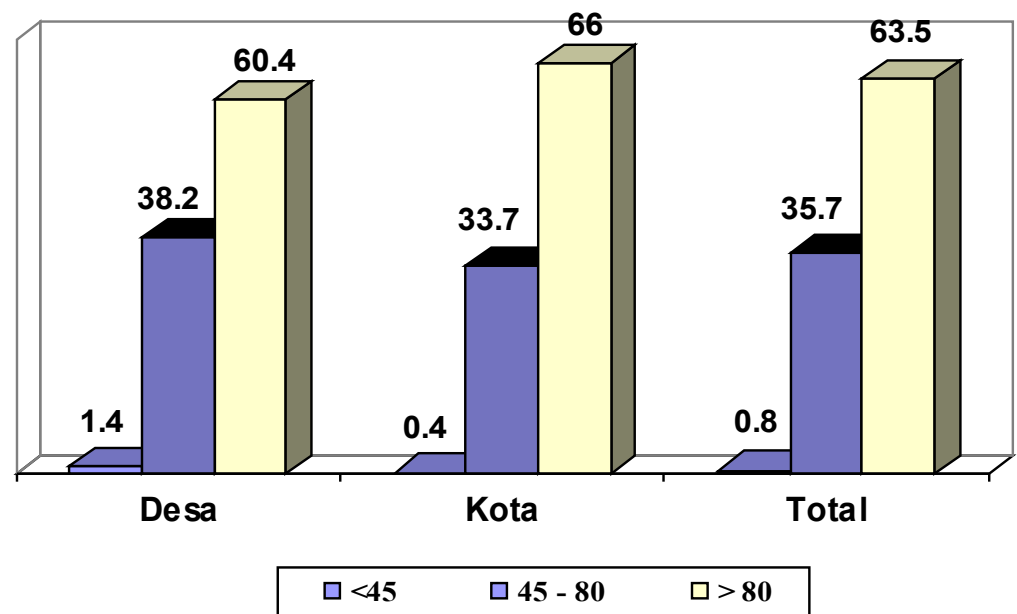

Gambar 4

Proporsi Kelenturan Kaki Kiri menurut Desa dan Kota

Gambar 4 menunjukkan lebih dari 60 persen lansia mampu mengangkat kaki kiri dengan sudut $>80$ derajat atau kategori baik walau lansia di kota proporsinya terlihat lebih tinggi dari lansia di desa. 


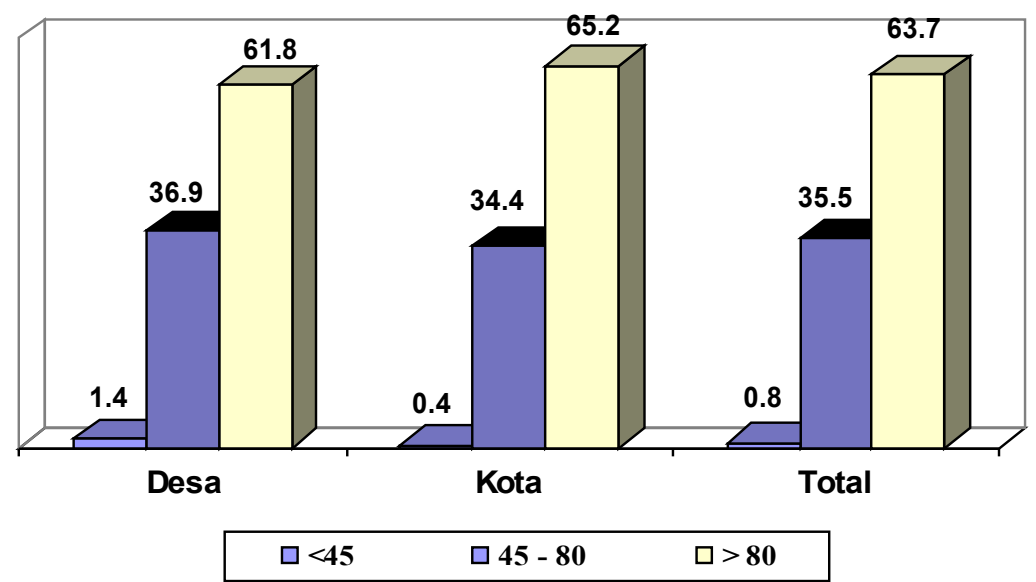

Gambar 5

Proporsi Kelenturan Kaki kanan menurut Desa dan Kota

Gambar 5 menunjukkan kelenturan kaki kanan lansia di desa 61,8 persen termasuk ke dalam kategori baik yaitu dapat mengangkat kaki kanan hingga lebih dari 80 derajat, sedangkan lansia di kota yang masuk ke dalam kategori baik (> 80 derajat) lebih tinggi dari pada lansia di desa yaitu 65.2 persen.

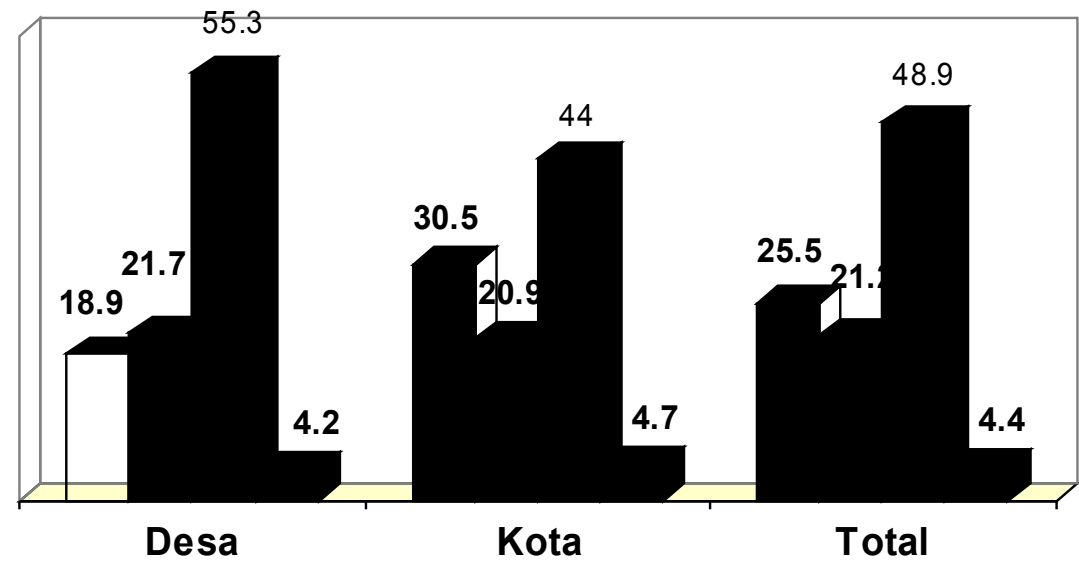

\section{$\square$ Kurang $\quad \square$ Sedang $\quad \square$ Cukup $\quad \square$ Baik}

Gambar 6

Proporsi Jangkauan Tangan menurut Desa dan Kota

Hasil pengukuran jangkauan tangan dengan cara "Sit \& Reach" menunjukkan lansia di desa kelenturannya lebih baik dari lansia di kota yaitu 18,9 persen dibanding 30,5 persen. Lansia di desa termasuk dalam kategori kurang sementara lansia yang termasuk dalam kategori kurang lebih tinggi yaitu 30,5 persen. Selain itu proporsi lansia di desa yang mempunyai kategori cukup lebih tinggi dibandingkan dengan di kota 
$(55,3 \%$ vs $44 \%)$. Namun baik lansia di desa maupun lansia di kota yang termasuk kategori baik proporsinya sangat kecil.

\section{Kekuatan Otot Genggam Tangan.}

Kekuatan otot genggam tangan lansia di desa baik tangan kiri maupun kanan termasuk dalam kategori sangat kurang dengan nilai rata-rata yaitu $25,8 \mathrm{~kg}$ untuk tangan kiri dan $27,2 \mathrm{~kg}$ untuk tangan kanan. Begitu juga di Kota rata-rata 26,1 kg untuk tangan kiri dan $27,3 \mathrm{~kg}$ untuk tangan kanan (Tabel 6).

Tabel 6

Sebaran Kategori Kekuatan Otot Genggam Tangan Kanan dan Kiri menurut Desa dan Kota

\begin{tabular}{|l|c|c|c|c|c|c|}
\hline \multirow{2}{*}{} & \multicolumn{2}{|c|}{ Desa (217) } & \multicolumn{2}{c|}{ Kota (282) } & \multicolumn{2}{c|}{ Total (499) } \\
\cline { 2 - 7 } & $\mathrm{n}$ & persen & $\mathrm{n}$ & persen & $\mathrm{n}$ & persen \\
\hline Kekuatan Otot Genggam & & & & & & \\
Kanan & & & & & & \\
1.Sangat Kurang & 215 & 99,1 & 273 & 96,8 & 488 & 97,8 \\
2. Kurang & 1 & 0,5 & 7 & 2,5 & 8 & 1,6 \\
3. Cukup & 0 & 0 & 1 & 0,4 & 1 & 0,2 \\
4. Baik & 1 & 0,5 & 1 & 0,4 & 2 & 0,4 \\
\hline Kekuatan Otot GenggamKiri & & & & & & \\
1.Sangat Kurang & 213 & 98,1 & 275 & 97,5 & 488 & 97,8 \\
2. Kurang & 3 & 1,4 & 4 & 1,4 & 7 & 1,4 \\
3. Cukup & 1 & 0,5 & 1 & 0,4 & 2 & 0,4 \\
4. Baik & 0 & 0 & 2 & 0,7 & 2 & 0,4 \\
\hline
\end{tabular}

\section{Ketahanan Kardiovaskuler}

Kemampuan kardiovaskuler diukur dengan sepeda statis selama 2 menit tanpa beban dilanjutkan selama 6 - 7 menit dengan beban $50 \mathrm{kpbs}$, dengan kecepatan sekitar 50 rpm. Perhitungan didasarkan pada perubahan nadi pada menit ke 5 dan ke 6 , yang disesuaikan dengan table tersedia. Dari 499 lansia yang terpilih, hanya 188 lansia, 70 responden dari desa dan 118 lansia dari kota yang mampu melakukan tes sampai selesai. Rata-rata ketahanan otot jantung paru yang ditunjukkan dengan nilai VO2 Max di desa adalah $23,1 \mathrm{cc} / \mathrm{kg}$ berat badan dan di kota lebih rendah yaitu $21,7 \mathrm{cc} / \mathrm{kg}$ berat badan. Dalam analisis selanjutnya lansia yang gagal dan yang tidak melakukan test diberi skor 0 (nol). Tabel 7 menunjukkan proporsi responden menurut kategori ketahanan jantung paru.

Tabel 7

Sebaran Kategori Ketahanan Kardiovaskuler menurut Desa dan Kota

\begin{tabular}{|c|c|c|c|c|c|c|}
\hline \multirow{2}{*}{$\begin{array}{c}\text { Kategori Ketahanan } \\
\text { Kardiovaskuler }\end{array}$} & \multicolumn{2}{|c|}{ Desa } & \multicolumn{2}{|c|}{ Kota } & \multicolumn{2}{|c|}{ Total } \\
\hline & $\mathrm{n}$ & $\%$ & $\mathrm{n}$ & $\%$ & $\mathrm{n}$ & $\%$ \\
\hline 1. Kurang sekali $<21$ & 170 & 78,3 & 232 & 82,6 & 402 & 80,7 \\
\hline Kurang $22-26$ & 28 & 12,9 & 38 & 13,5 & 66 & 13,3 \\
\hline 3. Cukup $27-35$ & 17 & 7,8 & 11 & 3,9 & 28 & 5,6 \\
\hline Baik $36-39$ & 1 & 0,5 & 0 & 0 & 1 & 0,2 \\
\hline Baik sekali > 40 & 1 & 0,5 & 0 & 0 & 1 & 0,2 \\
\hline
\end{tabular}

Hasil pengukuran dan dibandingkan dengan standar menunjukkan proporsi lansia di desa yang termasuk dalam kategori kurang dan kurang sekali lebih rendah $(91,2 \%)$ dibandingkan dengan lansia di kota dalam kategori yang sama $(96,1 \%)$ dengan 
nilai VO2 max kurang dari $27 \mathrm{cc} / \mathrm{kg}$ berat badan. Hanya 2 orang lansia yang berada dalam kategori baik dan baik sekali dan terdapat di desa.

\section{Komposisi Tubuh}

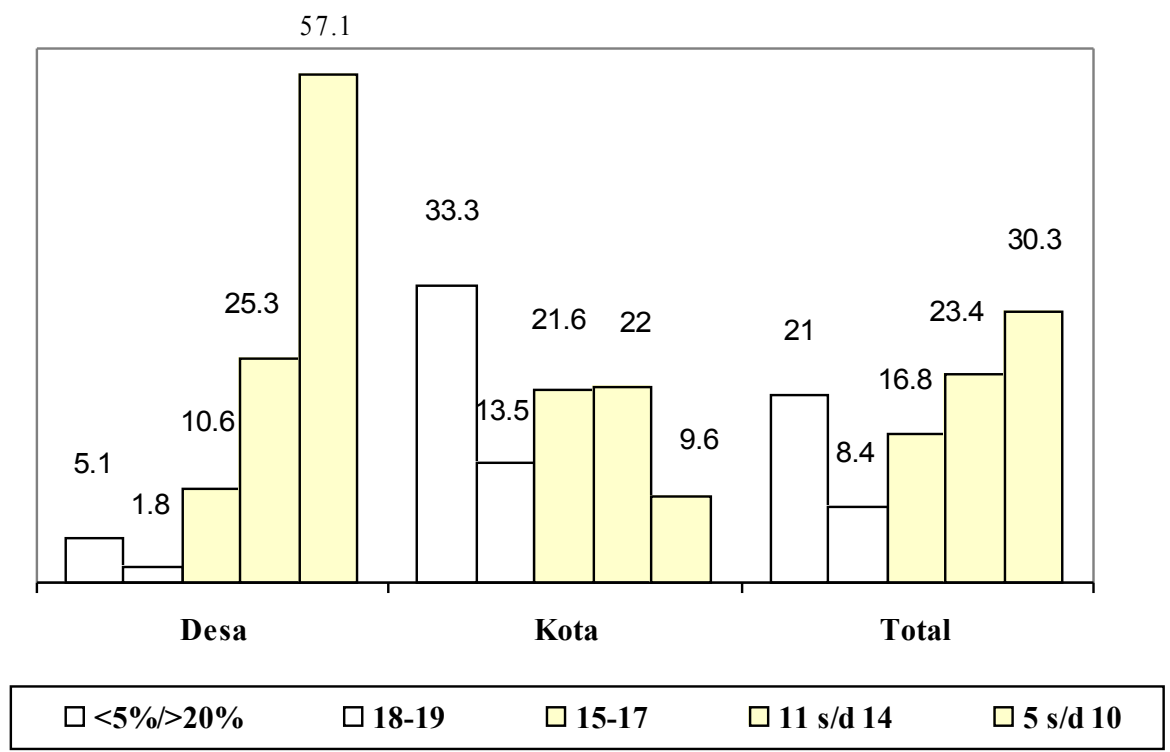

Gambar 7

Proporsi Persen Lemak Tubuh menurut Desa dan Kota

Proporsi lansia yang mempunyai lemak tubuh dengan nilai skor 1 yaitu persen lemak tubuh $<5$ persen atau $>20$ persen terlihat lebih tinggi pada lansia di kota yaitu 33,3 persen dinandingkan dengan lansia di desa hanya 5,1 persen. Lansia di desa 83,4 persen mempunyai lemak tubuh dalam kategori baik dan baik sekali (5 - $14 \%$ ), sementara lansia di kota hanya 31,6 persen dalam kategori yang sama.

\section{Kemampuan memori}

Kemampuan memori responden diukur dengan banyaknya barang-barang yang mampu diingat setelah tenggang waktu setengah jam dari waktu diperlihatkan kepada responden. Jenis barang yang diperlihatkan ada 10 macam dan merupakan barang-barang yang biasa mereka pergunakan sehari-hari.

Rata-rata jumlah barang yang bisa diingat adalah 6.9 pada Lansia di desa dan 7.1 pada lansia di kota.

Tingkat Kesegaran Jasmani Lansia Di Desa dan di Kota. 


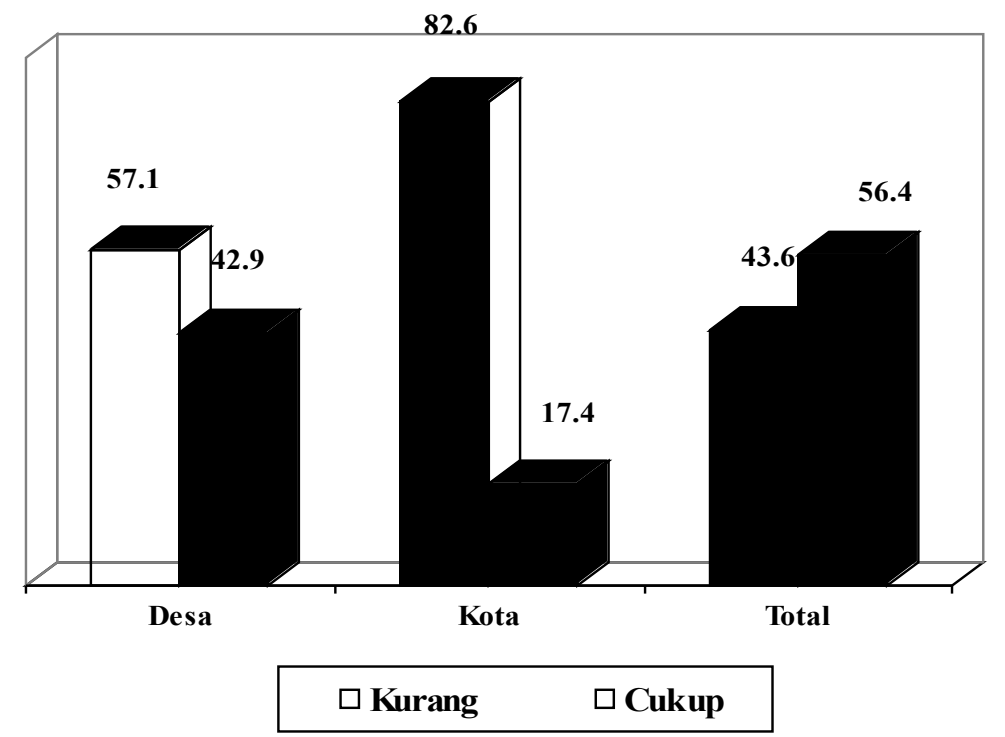

Gambar 8

Proporsi Tingkat Kesegaran Jasmani menurut Desa dan Kota

Hasil perhitungan berdasarkan 6 komponen kesegaran jasmani menunjukkan proporsi lansia dalam kategori kurang 57,1 persen dan menunjukkan proporsi yang lebih rendah dibandingkan dengan lansia di kota yang mencapai 82,6 persen pada kategori yang sama. Hasil analisis tabel silang menunjukkan ada hubungannya antara tingkat kesegaran jasmani dengan tempat tinggal lansia $(p<0,05)$.

\section{BAHASAN}

Pengukuran tingkat kesegaran jasmani dapat dilakukan dengan beberapa komponen pengukuran. Pada penelitian ini komponen yang diukur meliputi 6 komponen, yaitu keseimbangan tubuh (statis dan dinamis), kelenturan tubuh (kelenturan kaki dan metode Sit \& Reach), Kekuatan otot genggam tangan, komposisi tubuh, ketahanan kardiovaskuler dan kemampuan memori.

Hasil pengukuran kesegaran jasmani pada lansia tidak anemia di desa dan di kota menunjukkan beberapa komponen pengukuran menunjukkan hasil yang hampir sama. Komponen kelenturan tubuh, komposisi tubuh, dan ketahanan kardiovaskuler yang memberi kontribusi perbedaan ini seperti terlihat pada Gambar 6, Tabel 7 dan Gambar 7. Kelompok lansia merupakan kelompok yang heterogen yaitu keadaan gizi dan kesehatan sangat dipengaruhi oleh keadaan masa lalu dan masa sekarang.

Kelenturan tubuh lansia di desa kelenturanya lebih baik dari lansia di kota yaitu hanya 18,9 persen Lansia di desa termasuk dalam kategori kurang sementara lansia di kota yang termasuk dalam kategori kurang lebih tinggi yaitu 30,5 persen (Gambar 6). Namun kelenturan kaki terlihat di kota lebih tinggi. Latar belakang pekerjaan lansia pada usia produktif mungkin bisa menjelaskan hal ini. Lansia di desa sebagian besar bekerja di sektor informal sementara lansia di kota 49,1 persen merupakan pegawai negeri atau kantoran yang lebih banyak kegiatan duduk dan pada saat ini juga lansia di kota 67,3 persen tidak bekerja sementara lansia di desa 71,4 persen masih bekerja mencari nafkah (Tabel 2).

Ketahanan kardiovaskuler yang ditunjukkan pada tabel 7 menunjukkan lansia di desa yang termasuk dalam kategori kurang dan kurang sekali lebih rendah 
$(91,2 \%)$ dibandingkan dengan lansia di kota dalam kategori yang sama $(96,1 \%)$. Sedangkan rata-rata nilai VO2 Max di desa adalah $23,1 \mathrm{cc} / \mathrm{kg}$ berat badan dan di kota lebih rendah yaitu $21,7 \mathrm{cc} / \mathrm{kg}$ berat badan. Namun pengukuran ketahanan kardiovaskuler dengan menggunakan sepeda statis ini mempunyai kelemahan. Lansia yang tidak biasa/tidak pernah menggunakan sepeda tidak dapat melakukan pengukuran ini dengan baik, serta adanya penyakit sendi kaki dan hipertensi (tekanan darah > 150/100 mmHg) yang diderita juga mempengaruhi hasil. Perlu difikirkan untuk mencari metode pengukuran ketahanan kardiovaskuler yang cocok untuk lansia.

Proporsi lansia yang mempunyai lemak tubuh dengan nilai skor 1 yaitu persen lemak tubuh $<5$ persen atau $>20$ persen terlihat lebih tinggi pada Lansia di kota yaitu 33,3 persen dinandingkan dengan Lansia di desa hanya 5,1 persen. Lansia di desa 83,4 persen mempunyai lemak tubuh dalam kategori baik dan baik sekali ( $5-14 \%$ ), sementara lansia di kota hanya 31,6 persen dalam kategori yang sama. Asupan energi yang lebih tingi dibandingkan penggunaannya akan mengakibatkan akumulasi lemak dalam tubuh. Gambar 1 menunjukkan konsumsi energi lansia di kota yang konsumsi > 100 persen AKG lebih tinggi sementara kegiatannya sudah berkurang. Indeks Massa Tubuh lansia di kota menunjukkan rata-rata yang lebih tinggi dibandingkan lansia di desa. Menurut Jelliffe, 1984 memang ada korelasi antara IMT dengan akumulasi lemak tubuh dan ini akan berpengaruh terhadap tingkat kesegaran jasmaninya $^{(7)}$. Namun demikian kegiatan yang tidak diimbangi oleh asupan energi yang cukup juga akan menyebabkan kekurangan energi kronis.

\section{KESIMPULAN}

\section{Kesimpulan}

1. Proporsi lansia di kota yang tingkat kesegaran jasmaninya dengan kategori kurang lebih tinggi dibandingkan dengan Lansia di desa.

2. Komponen kelenturan tubuh, komposisi tubuh, dan ketahanan kardiovaskuler memberi kontribusi perbedaan antara tingkat kesegaran jasmani lansia di desa dan kota.

\section{Saran}

Perlu dicari metode yang cocok untuk mengukur ketahanan kardiovaskuler mengingat tidak semua lansia bisa menggunakan sepeda statis .

Upaya peningkatan kesegaran jasmani lansia harus terus ditingkatkan sehingga masa produktifitasnya bisa lebih lama, mengingat masih ada lansia yang masih bisa bekerja.

\section{RUJUKAN}

1. Biro Pusat Statistik. Demographic and Health Survey 1994. Jakarta. 1995.

2. Astrand P,MD and Kaare Rodahl,MD.Physiological bases of exercise.texbook of Work Physiology. Third Edition.Mc.Graw-Hill Book Company. 1986.

3. Pusat Pengkajian dan Pengembangan Iptek Olahraga. Panduan tehnis Tes dan Latihan Kesegaran Jasmani untuk Lanjut Usia. Seminar dan Widiakarya Nasional Olahraga dan Kesegaran Jasmani. Hotel Sahid jaya $6-7$ September 1999

4. Departemen Kesehatan RI. Pedoman Pengukuran Kesegaran Jasmani. Jakarta. 1994.

5. William P. Morley. Health and Physical Fitness. Saunders College Publishing 1982

6. Widyakarya Nasional Pangan dan Gizi VI. Angka Kecukupan Gizi. Jakarta. 1995.

7. Jellife DP \& EFP Jellif. Community nutrition Assessment with special reference to Less Technically Publications. New York. (1984). 
8. WHO Technical Report Series. Physical Status: The used and interpretation of Anthropometry. WHO Geneva. 1995.

9. Gibson RS. Principle of Nutritional Assessment.New York. Oxford University Press. 1990.

10. Shephard, R.J. Functional Recources of the cardiovascular system in old age 1991 in Sport for All. Elsevier Science Publisher (1991)
11. Shetty PS, CJK Henry, AE Black \& AM Prentice. Energy Requiements of Adult: an update om basal metabolic rates (BMRs) and Physical Activity Levels (PALs).European Journal of Clin. Nutr (1996) 50 Suppl 1: S11 - S 23.

12. Margetts BM, P.Little and Dwarm. Interaction between physical activity and diet: Implications for blood pressure management in primary care.Public Health Nutr. 2 (3a): 377 - 382. 